\title{
Dampak Perkembangan Sumber Keuangan Nagari Terhadap Inovasi Program Dan Kegiatan Pembangunan Nagari Di Kabupaten Solok Selatan Tahun 2013-2016
}

\section{Impact of Development of Nagari Financial Resources on Program Innovation and Nagari Development Activities in South Solok District 2013-2016}

\author{
Syamsurizaldi ${ }^{1}$, Annisa Aulia Putri ${ }^{2}$, Rozidateno Putri Hanida ${ }^{3}$, Suherdian Antoni ${ }^{4}$ \\ $(1,2,3,4)$ Staf Pengajar Universitas Andalas \\ s.rizaldi@yahoo.co.id,annisaau5@gmail.com \\ ozidateno@gmail.com,suherdian.antoni@gmail.com
}

Naskah Masuk : 09-04-2018 Naskah Diterima : 23-04-2018Ｎaskah Disetujui : 04-06-2018

\section{Abstract}

This study aims to determine the development of Nagari financial resources, know the development of innovations in Nagari development programs and activities, and find out the impact of the development of nagari financial resources on the innovation of nagari development programs and activities before and after the enactment of Law No. 6 of 2014 concerning Villages in South Solok Regency. The research method used is qualitative with interview and documentation data collection techniques. Descriptive analysis research type. The findings of this study are: 1) Nagari financial resources have increased by more than $100 \%$ in 2015 and 2016 as a result of the implementation of Law Number 6 of 2014 concerning Villages, but the nagari financial independence is very low, because of the small contribution of native nagari income, 2) shopping Nagari for development is still dominated for physical development, and is still lacking for empowerment activities. 3) the improvement of nagari financial resources has not had a significant impact on program planning innovations and nagari development activitie

Keyword : Innovation; Village Finance; Program; Activities; Nagari Development.

\begin{abstract}
Abstrak
Penelitian ini bertujuan untuk mengetahui perkembangan sumber keuangan Nagari, mengetahui perkembangan inovasi program dan kegiatan pembangunan Nagari, dan mengetahui dampak perkembangan sumber keuangan nagari terhadap inovasi program dan kegiatan pembangunan nagari sebelum dan setelah berlakunya UU Nomor 6 tahun 2014 tentang Desa di Kabupaten Solok Selatan. Metode penelitian yang digunakan adalah kualitatif dengan teknik pengumpulan data wawancara dan dokumentasi. Tipe penelitian analisis deskriptif. Temuan dari penelitian ini adalah: 1) sumber keuangan nagari mengalami peningkatan jumlah melbihi 100\% pada tahun 2015 dan 2016 sebagai akibat implementasi UU Nomor 6 tahun 2014 tentang Desa, namuun kemandirian keuangan nagari sangat rendah, karena kecil kontribusi pendapatan asli nagari, 2) belanja nagari untuk pembangunan masih didominasi untuk pembangunan fisik, dan masih kurang untuk kegiatan pemberdayaan. 3) peningkatan sumber keuangan nagari belum punya dampak yang berarit terhadap inovasi perencanaan program dan kegiatan pembangunann nagari.

Kata Kunci: Inovasi; Keuangan Desa; Program; Kegiatan; Pembangunan Nagari.
\end{abstract}

PENDAHULUAN

Disahkannya UU Nomor 6 tahun 2014 tentang Desa berimplikasi secara signifikan terhadap perubahan kebijakan dalam penyelenggaraan pemerintahan desa. UU Desa telah memberikan jaminan 
yang lebih pasti bahwa setiap desa akan menerima dana dari pemerintah melalui anggaran negara (APBN) dan daerah (APBD) yang jumlahnya berlipat, jauh diatas jumlah yang selama ini tersedia dalam anggaran desa. Kebijakan ini memiliki konsekuensi terhadap proses pengelolaannya yang seharusnya dilaksanakan secara profesional, efektif, efisien, serta akuntabel yang didasarkan pada prinsip-prinsip manajemen publik yang baik untuk percepatan pembangunan desa dan kawasan pedesaan.Mulai tahun anggaran 2015, sumber pembiayaan keuangan desa mengalami peningkatan yang signifikan karena dialokasikannya dana desa dari APBN disamping alokasi dana desa dari APBD Kabupaten/Kota.Kemudian, Desa juga dibolehkan menerima Bantuan Keuangan dari APBD Provinsi

Dana Desa dan Alokasi Dana Desa adalah sumber pendanaan yang cukup signifikan bagi desa untuk menopang pembiayaan program dan kegiatan pembangunan di desa. Pengelolaan keuangan desa menuntut keterlibatan tokoh-tokoh masyarakat dan aparatur pemerintah desa, baik dalam proses perencanaan anggaran sampai realisasi melalui forum musyawarah desa. Studi yang dilakukan oleh Komisi Pemberantasan Korupsi (KPK) tahun
2015 membuat estimasi besaran Alokasi Dana Desa yang dikucurkan berdasarkan formula PP Nomor 43 tahun 2014, serta Peraturan Presiden Nomor 162 tahun 2014 tentang besaran jumlah transfer dana dari pusat ke daerah. Sumber lainnya seperti bantuan keuangan dari APBD Provinsi, Dana Bagi Hasil Pajak dan Retribusi Daerah dari Kabupaten/Kota, Bantuan Pihak lainnya serta Pendapatan Asli Desajuga semakin memperbanyak sumber-sumber pembiayaan keuangan untuk APBDesa. Estimasi jumlah dan sumber keuangan Desa ini terus mengalami peningkatan tahun 2016sejalan dengan meningkatnya jumlah Dana Desa dari APBN dan meningkatnya dana transfer daerah dari Pemerintah Pusat (DAU) yang berimplikasi terhadap jumlah ADD dari Kabupaten/Kota. Artinya, secara kuantitafif besaran dan jumlah sumber keuangan desa telah mengalami peningkatan yang cukup signifikan dibandingkan dengan sebelum berlakunya UU Desa tahun 2014.

Peningkatan sumber keuangan desa dan jumlah anggaran yang dikelola oleh Desa idealnya berdampak terhadap peningkatan kesejahteraan masyarakat desa sebagai keluaran (outcome) dari program dan kegiatan yang tertuang dalam APBDesa.Pemerintahan Desa memilki kewenangan penuh dalam 
merumuskan kebijakan, program dan kegiatan pembangunan desa sesuai dengan ketentuan yang berlaku.Bervariasinya karakteristik desa di Indonesia seperti luas wilayah, jumlah penduduk, potensi sumber daya alam dan kualitas sumberdaya manusia, diperlukan inovasi dan kreasi dalam penyusunan program dan kegiatan pembangunan desa.

$$
\text { Kabupaten Solok Selatan }
$$

merupakan salah satu Kabupaten/Kota di Provinsi Sumatera Barat yang masih masuk dalam kategori daerah tertinggal,terdepan terluar bersama
Kabupaten Kepulauan Mentawai dan Kabupaten Pasaman Barat. Kabupaten Solok Selatan memiliki luas wilayah $3.501 \mathrm{~km} 2$ terdiri dari 7 Kecamatan dan 39 Desa (Nagari). Berdasarkan penelusuran terhadap dokumen-dokumen terkait dengan sumber-sumber pembiayaan keuangan desa, didapatkan data tentang perkembangan sumber keuangan desa yang berasal dari APBN dan APBD Kabupaten Solok Selatan tahun 2013-2016 seperti terdapat pada Tabel

Tabel 1 Perkembangan Sumber Keuangan Desa yang Berasal dari APBD Kabupaten, APBD Provinsi dan APBN di Kabupaten Solok Selatan Tahun 2013-2016

\begin{tabular}{lccccc}
\hline & \multicolumn{5}{c}{ Sumber Pembiayaan Keuangan Desa (Rp) } \\
\cline { 2 - 5 } Tahun & $\begin{array}{c}\text { Alokasi Dana } \\
\text { Desa }\end{array}$ & $\begin{array}{c}\text { Bagi Hasil } \\
\text { Pajak dan } \\
\text { Retribusi } \\
\text { Daerah }\end{array}$ & $\begin{array}{c}\text { BPB Pantuan } \\
\text { Keuangan }\end{array}$ & Dana Desa & Jumlah \\
\hline 2013 & 15.200 .291 .176 & 0 & 0 & 0 & 15.200 .291 .176 \\
\hline 2014 & 16.877 .220 .216 & 0 & 0 & 0 & 16.877 .220 .216 \\
\hline 2015 & 16.579 .909 .866 & 0 & 0 & 12.356 .228 .000 & 28.936 .137 .866 \\
\hline 2016 & 47.551 .500 .338 & 848.513 .129 & 0 & 27.729 .286 .000 & 76.129 .299 .467
\end{tabular}

Sumber: LKPD Kabupaten Solok Selatan (2013-2016), diolah 2017

Data pada Tabel menggambarkan bahwa pada tahun 2013 dan 2014 sumber pembiayaan keuangan Nagari dari Pemerintah hanya berasal dari ADD yang saat itu menggunakan istilah Dana Alokasi Umum Nagari (DAUN) yang digunakan untuk belanja operasional pemerintahan nagari dengan besarannya bervariasi sesuai dengan indikator potensi nagari seperti luas wilayah, jumlah penduduk, jarak ke Ibukota Kabupaten dan lain sebagainya. Sedangkan sumber pembiayaan untuk pembangunan dialokasikan dengan jumlah yang sama setiap nagari disebut Dana Block Grand Nagari. Jika dibandingkan dengan 
formulasi sesuai PP Nomor 72 Tahun 2005 tentang Desa, Pemerintah Kabupaten Solok Selatan belum mengalokasikan sesuai batas minimal 10\% dari DAU setelah dikurangi belanja pegawai. Hal yang sama juga masih terjadi pada tahun 2015.

Sejalan dengan lahirnya UU Nomor 6 tahun 2014 tentang Desa, dan adanya ketegasan untuk mengalokasikan ADD, maka Pemerintah Kabupaten Solok Selatan baru memenuhi ketentuan minimal 10\% ADD mulai tahun 2016, termasuk mengalokasikan Dana Bagi Hasil Pajak dan Retribusi Daerah untuk Desa (Nagari). Sementara itu, pada tahun 2015 dan 2016 Kabupaten telah mendapatkan transfer berupa Dana Desa dari APBN dengan jumlah yang meningkat lebih dari 100\%.

Dilihat dari total sumber keuangan desa tahun 2013 sampai dengan 2016, telah mengalami kenaikan secara signifikan dimana pada tahun 2013 sebesar Rp. 15,2 Milyar, naik menjadi Rp. 16,9 Milyar tahun 2014, naik menjadi Rp. 28,9 Milyar tahun 2015 dan naik drastis menjadi Rp. 76,1 Miliar tahun 2016. Peningkatan sumber-sumber pembiayaan keuangan desa, diduga belum diikuti dengan inovasi kebijakan, program dan kegiatan pembangunan desa sebagai strategi dalam meningkatkan kesejahteraan masyarakat desa.

Beberapa studi sebelumnya menemukan bahwa pengelolaan ADD untuk pembangunan fisik belum tepat sasaran (Nurliana, 2013), pengelolaan ADD belum efektif karena pos-pos anggarandalam pemanfaatan ADD tidak sesuai dengan kebutuhan desa, dan beberapa faktor penghambat pengelolaan ADD sehingga belum efektif menurut Okta (2004) yaitu: a) manajemen organisasi pemerintahah desa yang kurang baik; b) sumber daya manusia yang kurang; c) kurangnya sarana dan prasarana; dan d) kurangnya partisipasi masyarakat. Kemudian Studi Azwardi dan Sukanto (2014) menemukan pengaruh negatif antara ADD terhadap tingkat kemiskinan, artinya semakin besar jumlah ADD maka semakin kecil tingkat kemiskinan. Namun secara lebih detail dalam studi ini juga ditemukan hal yang menarik yaitu nilai koefisien ADD menunjukkan nilai -0,0000077, hal ini bermakna bahwa bila ADD meningkat 1 \% maka kemiskinan akan berkurang sebanyak 0, 0000077\%. Artinya pengaruh ADD terhadap kemiskinan dalam kategori sangat kecil.

Ada dua hal yang menjadi urgensi dari peneltian ini. Pertama, untuk mengetahui dan mengidentifikasi jenis 
dan sumber-sumber keuangan di nagari sebelum dan setelah berlakunya UU Nomor 6 tahun 2014 tentang Desa. Perubahan kebijakan memberi implikasi terhadap perubahan sumber-sumber keuangan di nagari. Walaupun secara aturan sudah bisa di lihat, namun kegiatan identifikasi ini tetap perlu dilakukan untuk melihat sumber keuangan riil di nagari yang ada di Kabupaten Solok Selatan, karena kemandirian atau tingkat ketergantungan nagari terhadap pemerintahan yang diatasnya akan membuat sumber keuangan ini akan beragam.Kedua, Proses penyusunan program dan kegiatan di nagari selama ini diduga masih sangat berorientasi pada pembangunan fisik, mengakibatkan rendahnya inovasi yang dilakukan oleh pemerintah nagari. Asumsi awal penelitian ini adalah semakin beragamnya sumber keuangan yang dimiliki oleh pemerintahan nagari maka semakin inovatif pemerintahan nagari dalam menyusun program dan kegiatan pembangunan di nagarinya.Berdasarkan hal yang di gambarkan pada bagian atas, tulisan ini ditujukan untuk Untuk mendeskripsikan perkembangan sumber keuangan nagari sebelum dan setelah berlakunya UU Nomor 6 tahun 2014 tentang Desa di Kabupaten Solok Selatan. Kemudian untuk mendeskripsikam inovasi dalam penyusunan program dan kegiatan pembangunan nagari sebelum dan setelah berlakunya UU Nomor 6 tahun 2014 tentang Desa di Kabupaten Solok Selatan. Sehingga kemudian bisa dideskripsikan dampak perkembangan sumberkeuangan nagari terhadap inovasi penyusunan program dan kegiatan pembangunan nagari sebelum dan setelah berlakunya UU Nomor 6 tahun 2014 tentang Desa di Kabupaten Solok Selatan. Tulisan ini adalah salah satu hasil akhir dari penelitian yang berjudul Dampak Perkembangan Sumber Keuangan Nagari terhadap Inovasi Program dan Kegiatan Penbangunan Nagari di Kabupaten Solok Selatan Tahun 2013-2016.

Penelitian dilakukan dengan menggunakan metode penelitian deskriptif dengan pendekatan kualitatif untuk melihat bagaimana inovasi dalam penyusunan program dan kegiatan pembangunan nagari sebelum dan setelah berlakunya UU Nomor 6 tahun 2014 tentang Desa di Kabupaten Solok Selatan.Pendekatan ini ditujukan untuk mempelajari fenomena sosial dengan tujuan menjelaskan dan menganalisa perilaku manusia dan kelompok, dari sudut pandang yang sama sebagai objek yang diteliti melihat masalah tersebut (Moleong, 2000: 3).Dengan upaya membatasi lokasi penelitian pada nagari- 
nagari yang tidak mengalami proses pergantian kepemimpinan pada rentang waktu yang ditentukan, membantu peneliti untuk melihat berbagai faktor penghalang inovasi, seperti halnya disebutkan dalam pendekatan teoritik penelitian ini. Untuk mendapatkan hasil yang diharapkan maka peneliti menggunakan pendekatan kualitatif. Penelitian kualitatif menurut (Strauss Corbin:1990:17) adalah "qualitatif research we mean any kind of research that produces finding not arrived at by means of statistical procedures or other means quantification". Penelitian ini menjadikan Nagari di Kabupaten Solok Selatan sebagai lokus penelitian. Dari 39 Nagari yang ada dipilih sebagai sampel yaitu 1 Nagari setiap Kecamatan dengan kriteria pokok dimana pada Nagari yang menjadi lokus tidak terjadi pergantian kepemimpinan Wali Nagari selama tahun 2013-2016. Kriteria ini untuk memastikan bahwa inovasi dalam penyusunan program dan kegiatan pembangunan desa dilaksanakan oleh pemimpin yang sama dan perubahan yang terjadi bukan disebabkan oleh perubahan kepemimpinan, akan tetapi disebabkan oleh adanya kreasi yang dilakukan sebagai dampak dari perkembangan sumber-sumber pembiayaan keuangan Nagari sesuai ketentuan yang berlaku.
Lokasi penelitian berada pada 7 (tujuh) nagari, dimana masing-masing kecamatan diwakili oleh satu nagari sesuai kriteria pokok yang ditentukan dalam penelitian ini. Adapun nagari tersebut adalah: Lubuk Gadang Timur Kecamatan Sangir, Pulakek Koto Baru Kecamatan Sungai Pagu, Pakan Rabaa Utara Kecamatan Koto Parik Gadang Diateh, Padang Air Dingin Kecamatan Sangir Jujuan, Sungai Kunyit Barat Kecamatan Sangir Balai Janggo dan Dusun Tangah Kecamatan Sangir Batang Hari.

\section{Inovasi Program dan Kegiatan Pemerintahan Nagari}

Amanah UU Nomor 6 tahun 2014 di tujukan agar daerah dalam hal ini pemerintahan desa/Nagari harus mampu dan mau mewujudkan kemandirian nagari. Kemandirian ini bisa di dorong dengan membangun hubungan yang selaras dan harmonis dengan masyarakat dan dunia usaha untuk mewujudkan tata pemerintahan yang baik (Good governance). Agar hubungan yang dimaksud dapat selaras dan harmonis, pemerintah perlu melakukan reposisi sebagai motivator, dinamisator dan inisiator, sehingga kewenangan yang dimiliki mampu menghantarkan masyarakat pada kondisi kehidupan yang layak, makmur dan sejahtera. 
Disinilah diperlukan adanya daya inovatif pemerintahan nagari dalam mewujudkan makmuran dan kesejahteraan. Daya inovasi yang dimaksud dalam penelitian ini adalah kemampuan pemerintah nagari dalam menghasilkan kreatifitas dalam penyusunan program dan kegiatan di nagari. Dalam tulisan yang di edit oleh
Ian McPhee (2009)Innovation in a public sector context has been defined as the 'creation and implementation of new processes, products, services and methods of delivery which result in significant improvements in the efficiency, effectiveness or quality of outcomes'. In short, innovationis the application of new ideas to produce better outcomes.

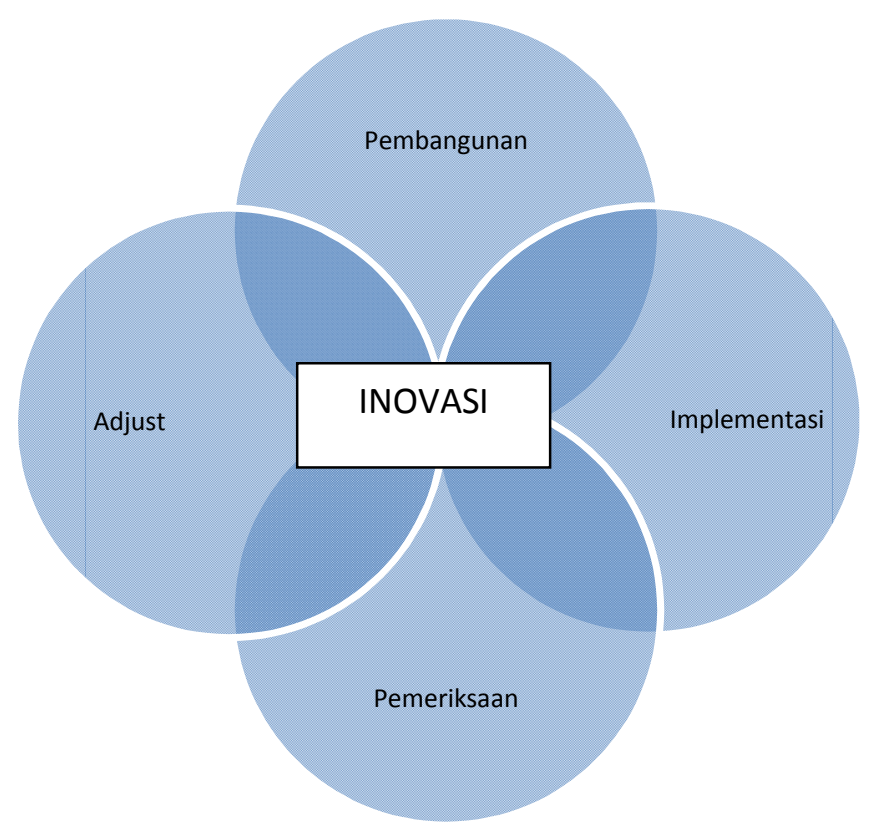

Untuk melakukan inovasi tersebut, maka ada syarat pra kondisi yang harus dimiliki oleh daerah dalam melakukan layanan di sektor publik tersebut, ini di sadur dari buku panduan yang disusun oleh Ian McPhee (2009). Kepemimpinan, strategi pengembangan kelembagaan dan sumberdaya manusia menjadi hal hal yang perlu mendapat perhatian sebagai pra kondisi yang perlu diciptakan untuk melakukan inovasi.
Dalam tulisan Drucker (1986), berpendapat bahwa setiap organisasi perlu suatu kompetensi inti (core competence), yaitu inovasi. Inovasi mendorong pertumbuhan organisasional, meningkatkan keberhasilan masa yang akan datang, dan merupakan mesin yang memungkinkan organisasi bertahan dari kerentanan (viability). Dalam penyusunan program dan kegiatan di nagari di butuhkan daya inovasi tersebut. Yang mana inovasi tersebut dapat dilihat dalam 
proses pembuatan kebijakan, dilakukannya. Salah satu hal yang penting pelaksananaan kebijakan dan untuk diperhatikan dalam mendukung mengevaluasi kebijakan. Dalam penelitian proses pelaksanaan pembangunan di ini adalah kebijakan pemerintahan nagari setiap nagari adalah adanya kepastian yang dilakukan oleh stakeholder nagari dalam penyusunan program dan kegiatan di nagari dengan kondisi dimana sumber pembiayaan di nagari yang semakin beragam dan semakin meningkat.

\section{Sumber Keuangan Nagari}

Untuk percepatan kemandirian nagari dalam kerangka otonomi daerah maka pemerintah dan pemerintah daerah mendorong Pemerintah Nagari untuk lebih memberdayakan masyarakat dan mengoptimalkan sumberdaya yang ada, baik itu sumberdaya dari nagari sendiri maupun dari luar. Nagari memiliki kewenangan untuk mengatur dan mengurus rumah tangganya sesuai dengan kewenangan asli maupun kewenangan penugasan dari pemerintahan tingkat atas, yang menyangkut peranan pemerintah nagari sebagai penyelenggara pelayanan publik di nagari dan sebagai pendamping dalam proses perencanaan dan pelaksanaan pembangunan daerah yang melibatkan masyarakat di tingkat nagari. Untuk melaksanakan kewenangan tersebut, pemerintah nagari memiliki sumber-sumber keuangan yang digunakan untuk membiayai kegiatan-kegiatan yang

keuangan untuk pembiayaannya. Pendapatan Desa meliputi semua penerimaan uang melalui Rekening Kas Desa yang merupakan hak desa dalam 1 (satu) tahun anggaran yang tidak perlu dibayar kembali oleh desa. Pendapatan desa bersumber dari (pasal 72 UU No 6/2014 tentang Desa):

1) Pendapatan Asli Daerah, terdiri dari :

a. Hasil usaha

b. Hasil aset

c. Swadaya dan partisipasi

d. Gotong royong

e. Lain-lain PADes

2) Alokasi Anggaran Pendapatan dan Belanja Negara (Dana Desa),Pemerintah mengalokasikan dana nagari dalam APBN setiap tahun anggaran yang diperuntukkan bagi nagari yang ditransfer melalui APBD Kabupaten/Kota.

3) Bagian Hasil Pajak Daerah dan Retribusi Daerah Kabupaten/Kota, Pemerintah Kabupaten/Kota mengalokasikan bagian hasil dari hasil pajak dan retribusi daerah kabupaten/kota kepada nagari minimal $10 \%$ dari realisasi penerimaan hasil pajak dan retribusi 
daerah

kabupaten/kota.

Pengalokasian bagian hasil pajak dan retribusi daerah tersebut dilakukan berdasarkan ketentuan 60\% dibagi secara merata kepada seluruh nagari dan $40 \%$ dibagi secara proporsional realisasi penerimaan hasil pajak dan retribusi daerah masing-masing.

4) Alokasi Dana Desa, yang merupakan bagian dari dana perimbangan yang diterima Kabupaten. Pemerintah Kabupaten/Kota mengalokasikan ADD dalam APBD setiap tahun anggaran minimal $10 \%$ dari dana perimbangan yang diterima kabupaten/kota dalam APBD setelah dikurangi DAK. Pengalokasian ADD mempertimbangkan kebutuhan penghasilan tetap wali nagari dan perangkat nagari serta jumlah penduduk nagari, angka kemiskinan nagari, luas wilayah nagari dan tingkat kesulitan geografis nagari.

5) Bantuan Keuangan dari APBD Provinsi dan APBD Kabupaten/Kota, Pemerintah Provinsi/Kabupaten/Kota dapat memberikan bantuan keuangan yang bersumber dari APBD Provinsi/Kabupaten/kota kepada nagari/desa, baik yang bersifat umum maupun khusus. Bantuan yang bersifat umum peruntukkan dan penggunaannya diserahkan sepenuhnya kepada nagari penerima bantuan dalam rangka membantu pelaksanaan tugas pemerintah daerah di nagari. Bantuan yang bersifat khusus peruntukkan dan pengelolaannya ditetapkan oleh pemerintah darah pemberi bantuan dalam rangka percepatan pembangunan nagari dan pemberdayaan masyarakat

6) Hibah dan Sumbangan yang Tidak Mengikat dari Pihak Ketiga;

7) Lain-lain Pendapatan Desa yang Sah, Seluruh pendapatan nagari diterima dan disalurkan melalui rekening kas nagari dan penggunaannya ditetapkan dalam APB Nagari.

Pendapatan Desa tersebut jika diklasifikasikan menurut kelompok terdiri dari :

1) Pendapatan Asli Desa (PADesa)

2) Transfer

3) Pendapatan Lain-Lain

\section{Pengelolaan Keuangan Nagari}

Keuangan Nagari dikelola berdasarkan azas-azas transparan, akuntabel, partisipatif serta dilakukan dengan tertib dan disiplin anggaran. Pengelolaan keuangan nagari meliputi perencanaan, pelaksanaan, penatausahaan, pelaporan dan pertanggungjawaban.

a. Perencanaan 
Dokumen

perencanaan

keuangan nagari meliputi RPJM Nagari dan RKP Nagari yang berpedoman kepada perencanaan pembangunan daerah yang disusun berdasarkan hasil kesepakatan dalam musyawarah nagari. Musyawarah nagari dilaksanakan paling lambat bulan Juni tahun anggaran berjalan. Penyusunan RPJM Nagari dan RKP Nagari dilakukan secara partisipatif dalam forum musyawarah perencanaan pembangunan nagari yang melibatkan Badan

Permusyawaratan Nagari dan unsur masyarakat nagari. RPJM Nagari memuat penjabaran visi dan misi Wali Nagari, rencana penyelenggaraan pemerintahan nagari, pelaksanaan pembangunan, pembinaan kemasyarakatan, pemberdayaan masyarakat dan arah kebijakan perencanaan pembangunan nagari.

RPJM Nagari mengacu visi dan misi Wali Nagari terpilih dan diselaraskan dengan RPJM Kabupaten/Kota dengan mempertimbangkan kondisi obyektif nagari dan prioritas pembangunan kabupaten/kota. RPJM Nagari ditetapkan dalam jangka waktu paling lama tiga bulan terhitung sejak pelantikan Wali Nagari. Nagari memuat rencana penyelenggaraan pemerintahan nagari, pelaksanaan pembangunan, pembinaan kemasyarakatan, pemberdayaan masyarakat nagari. RKP Nagari berisi evaluasi pelaksanaan RKP Nagari tahun sebelumnya, prioritas program, kegiatan, dan anggaran nagari yang dikelola oleh nagari maupun melalui kerja sama antara nagari/pihak ketiga serta kewenangan penugasan dari tingkatan pemerintah yang lebih tinggi. RKP Nagari mulai disusun oleh pemerintah nagari pada bulan Juli tahun berjalan dan ditetapkan dengan peraturan nagari paling lambat akhir bulan September tahun berjalan. RKP Nagari menjadi dasar penetapan APB Nagari.

b. Penganggaran

APBNagari terdiri dari Pendapatan, Belanja dan Pembiayaan Nagari. Pendapatan adalah semua penerimaan uang melalui rekening nagari yang merupakan hak nagari dalam satu tahun anggaran yang tidak perlu dibayar kembali oleh nagari. Peraturan Nagari tentang APB Nagari ditetapkan paling lambat tanggal 31 Desember tahun anggaran berjalan.

Belanja nagari meliputi semua pengeluaran dari rekening nagari 
yang merupakan kewajiban nagari dalam satu tahun anggaran yang tidak akan diperoleh pembayarannya kembali oleh nagari. Belanja nagari terdiri dari belanja langsung dan belanja tidak langsung. Belanja langsung terdiri dari belanja pegawai, barang dan modal. Belanja tidak langsung terdiri dari belanja pegawai/penghasilan tetap, belanja subsidi, bantuan sosial, bantuan keuangan dan belanja tidak terduga. Belanja nagari yang ditetapkan dalam APBNagari digunakan minimal 70\% untuk mendanai penyelenggaraan pemerintahan nagari, pelaksanaan pembangunan nagari, pembinaan kemasyarakatan nagari, dan pemberdayaan masyarakat nagari, serta digunakan minimal $30 \%$ untuk penghasilan tetap dan tunjangan kepala nagari dan perangkat nagari, operasional pemerintah nagari, tunjangan dan operasional BPN dan insentif rukun tetangga dan rukun warga.

c. Pelaksanaan

Wali Nagari adalah pemegang kekuasaan pengelolaan keuangan nagari yang dalam pelaksanaannya dapat dikuasakan kepada perangkat nagari. Perangkat nagari terdiri atas sekretariat nagari, pelaksana kewilayahan dan pelaksana teknis. Perangkat nagari berkedudukan sebagai unsur pembantu wali nagari. Sekretariat nagari dipimpin oleh sekretaris nagari dibantu oleh unsur staf sekretariat yang bertugas membantu wali nagari dalam bidang administrasi pemerintahan. Pelaksana kewilayahan merupakan unsur pembantu wali nagari sebagai satuan tugas kewilayahan. Pelaksana teknis merupakan unsur pembantu wali nagari sebagai pelaksana tugas operasional. Pelaksana teknis pengelolaan keuangan nagari adalah perangkat nagari yang ditunjuk oleh wali nagari untuk melaksanakan pengelolaan keuangan nagari. Bendahara adalah perangkat nagari yang ditunjuk oleh wali nagari untuk menerima, menyimpan, menyetorkan, menatausahakan, membayarkan, dan mempertanggungjawabkan keuangan nagari dalam rangka pelaksanaan APB Nagari. Pencairan dana dalam rekening kas nagari ditandatangani oleh wali nagari dan bendahara nagari.

d. Pelaporan dan Pertanggungjawaban

Wali Nagari menyampaikan laporan realisasi pelaksanaan APBNag kepada Bupati setiap semester tahun berjalan dan setiap 
akhir tahun anggaran. Format pertanggungjawaban yang disajikan dalam peraturan menteri dalam negeri terkait hanya ditujukan untuk bendahara. Laporan pertanggungjawaban tersebut meliputi laporan pertanggungjawaban penerimaan dan laporan pertanggungjawaban pengeluaran. Laporan pertanggungjawaban penerimaan dilampirkan dengan buku kas umum, buku kas pembantu perincian obyek penerimaan dan bukti penerimaan lainnya yang sah. Laporan pertanggungjawaban pengeluaran dilampirkan dengan buku kas umum, buku kas pembantu perincian obyek pengeluaran yang disertai dengan bukti-bukti pengeluaran yang sah dan bukti atas penyetoran PPN atau PPh ke kas Negara.

\section{Perkembangan Sumber Keuangan}

\section{Nagari di Kabupaten Solok Selatan}

Dampak dari berlakunya UU Nomor 6 Tahun 2014 tentang Desa pada perkembangan sumber keuangan Nagari di Kabupaten Solok Selatan adalah meningkatnya pendapatan Nagari. Peningkatan tersebut terjadi karena mulai tahun anggaran 2015, diberlakukan pengalokasian Dana Desa yang bersumber langsung dari APBN, disamping Alokasi Dana Desa dari APBD Kabupaten/Kota. Nagari juga diperbolehkan menerima bantuan keuangan dari APBD Provinsi. Dalam UU ini, dijelaskan dengan tegas bahwa Desa menerima Alokasi Dana Desa paling sedikit $10 \%$ dari dana perimbangan yang diterima Kabupaten/Kota dalam APBD setelah dikurangi Dana Alokasi Khusus.Peningkatan Sumber Keuangan Nagari di Kabupaten Solok Selatan terlihat jelas pada grafik 1

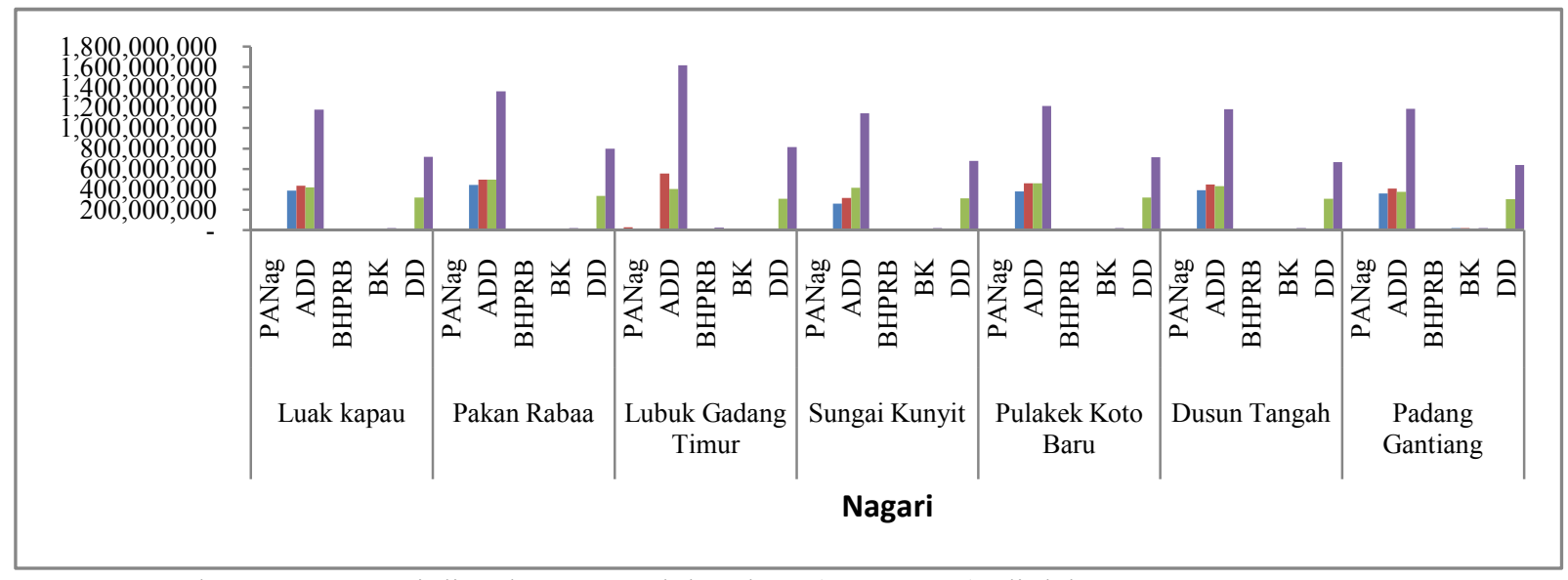

Sumber : APBNagari di Kabupaten Solok Selatan(2013-2016), diolah.

Gambar 1 Perkembangan Sumber Keuangan Nagari di Kabupaten Solok Selatan dari tahun 2013-2016 
Grafik 1 memperlihatkan bahwa peningkatan sumber pembiayaan keuangan Nagari secara signifikan terjadi pada tahun 2016. Sumber keuangan nagari terbesar berasal dari Alokasi Dana Desa. Sebelum diberlakukan UU Nomor 6 Tahun 2014 tentang Desa, pengalokasian dana desa oleh Pemerintah Kabupaten Solok Selatan berdasarkan formulasi PP Nomor 72 tahun 2005 tentang Desa. Pengalokasian tersebut masih kurang dari 10\% dari DAU setelah dikurangi belanja pegawai. Pada diagram di atas terlihat jelas setelah diberlakukannya UU Nomor 6 tahun 2014 tentang Desa, yang didalamnya diatur secara tegas terkait alokasi dana desa, Pemerintah Kabupaten Solok Selatan mulai memenuhi ketentuan minimal 10\% ADD mulai tahun 2016, sehingga terlihat peningkatan yang signifikan terhadap pendapatan Nagari.

Alokasi Dana Desa di Kabupaten Solok Selatan mulai meningkat drastis pada tahun 2016. Nagari yang mengalami peningkatan ADD tertinggi yaitu Nagari Lubuk Gadang Timur, dengan peningkatan 300\% dari Rp 403.769 .000 menjadi Rp 1.614.870.000. begitu juga dengan nagari lain mengalami peningkatan lebih dari 100\%.Selain Alokasi Dana Desa, Nagari juga memperoleh transfer berupa Dana Desa yang berasal dari APBN dimulai dari tahun 2015. Transfer Dana Desa tersebut mengalami peningkatan lebih dari $100 \%$ mulai tahun 2015 dan 2016. Nagari Luak Kapau Alam Pauh Duomengalami peningkatan $\quad \mathrm{DD} \quad 125 \%$ dari $\mathrm{Rp}$ 318.467.473 di tahun 2015 menjadi $\mathrm{Rp}$ 718.078.000 di tahun 2016. Begitujuga dengan Nagari Pakan Rabaa Utara meningkat 138\% dari Rp 366.503.684 menjadi Rp 801.291.000, Nagari Lubuk Gadang Timur 165\% dari Rp 308.792.651 menjadi Rp 816.789.000, Nagari Sungai Kunyit meningkat $119 \%$ dari $\mathrm{Rp}$ 309.667.480 menjadi Rp 678.206.000, Nagari Pulakek Koto Baru meningkat $126 \%$ dari $\operatorname{Rp} 318.313 .701$ menjadi 717.831.000, dan Nagari Dusun Tangah meningkat $118 \%$ dari $\mathrm{Rp} 307.831 .248$ menjadi Rp 669.735.000.

Secara keseluruhan, terlihat perbedaan pendapatan Nagari sebelum dan sesudah diberlakukannya UUNomor 6 tahun 2014 tentang Desa. Dari tahun 2013 ke 2014, peningkatan sumber keuangan nagari yaitu dibawah 50\%, dari tahun 2014 ke tahun 2015 mulai terjadi peningkatan lebih dari $50 \%$, dan dari tahun 2015 ke 2016 terjadi peningkatan sumber keuangan nagari lebih dari 100\%.

Setelah implemnetasiUUNomor 6 tahun 2014 tentang Desa, Sumber 
Keuangan nagari mulai memiliki banyak variasi. Variasi tersebut dijelaskan dalam pasal 72 terdiri dari tujuh sumber keuangan desa, yaitu Pendapatan Asli Desa, Alokasi Anggaran Pendapatan dan Belanja Negara (APBN), Bagian Hasil Pajak Daerah dan Retribusi Daerah Kabupaten/Kota, Hibah dan Sumbangan yang Tidak Mengikat dari pihak ketiga.Sumber keuangan nagari yang beragam ditujukan untuk menumbuhkan semangat berinovasi Nagari. Pengalokasian sumber keuangan nagari tersebut untuk berbagai kegiatan nagari juga diatur. Misalnya dana desa ditujukan untuk pemberdayaan masyarakat, alokasi dana desa untuk pembangunan, dan lainlain yang tujuan akhirnya meningkatkan partisipasi masyarakat untuk membangun Nagari, bukan hanya fisik tapi juga non fisik menuju kemandirian Nagari.

Amanah UU Nomor 6 tahun 2014 di tujukan agar daerah dalam hal ini pemerintahan desa/Nagari harus mampu dan mau mewujudkan kemandirian nagari. Kemandirian ini bisa di dorong dengan membangun hubungan yang selaras dan harmonis dengan masyarakat dan dunia usaha untuk mewujudkan tata pemerintahan yang baik (Good governance). Agar hubungan yang dimaksud dapat selaras dan harmonis, pemerintah perlu melakukan reposisi sebagai motivator, dinamisator dan inisiator, sehingga kewenangan yang dimiliki mampu menghantarkan masyarakat pada perikehidupan yang layak, makmur dan sejahtera. Dengan banyaknya variasi sumber Keuangan Desa, Nagari harus mampu berinovasi untuk mewujudkan kemandirian nagari tersebut.

\section{Kondisi Pembangunan Nagari di} Kabupaten Solok Selatan

Peningkatan sumber keuangan Nagari ditujukan bukan hanya untuk melakukan pembangunan fisik, namun diutamakan untuk mendorong partisipasi masyarakat dan peningkatan taraf hidup mereka. Ada delapan tujuan alokasi dana desa, yang apabila disimpulkan secara umum, alokasi dana desa bertujuan untuk pembangunan fisik dan non fisik dalam mendorong partisipasi masyarakat dalam pembangunan. pada umumnya, alokasi dana desa merupakan sumber keuangan utama di Nagari. Hal ini dikarenakan rendahnya kontribusi pendapatan asli nagari. Sebelum tahun 2015, nagari memiliki pendapatan asli nagari melalui pengurusan surat-surat izin. Namun sejak tahun 2015 Nagari tidak diperbolehkan lagi mengambil pungutan dari pengurusan surat-surat. Sebagai sumber pembiayaan utama nagari, aparatur desa diharapkan 
mampu memposisikan ADD sebagai stimultan pemberdayaan masyarakat, bukan hanya pembangunan fisik yang bermanfaat jangka pendek, dan kecil kontribusinya untuk pemberdayaan masyarakat.
Kurang terarahnya pengalokasian dana desa di Kabupaten Solok Selatan terlihat dari lebih dominannya alokasi anggaran untuk pembangunan fisik dibandingkan program-program pemberdayaan masyarakat, hal tersebut dapat dilihat pada Grafik.2 :

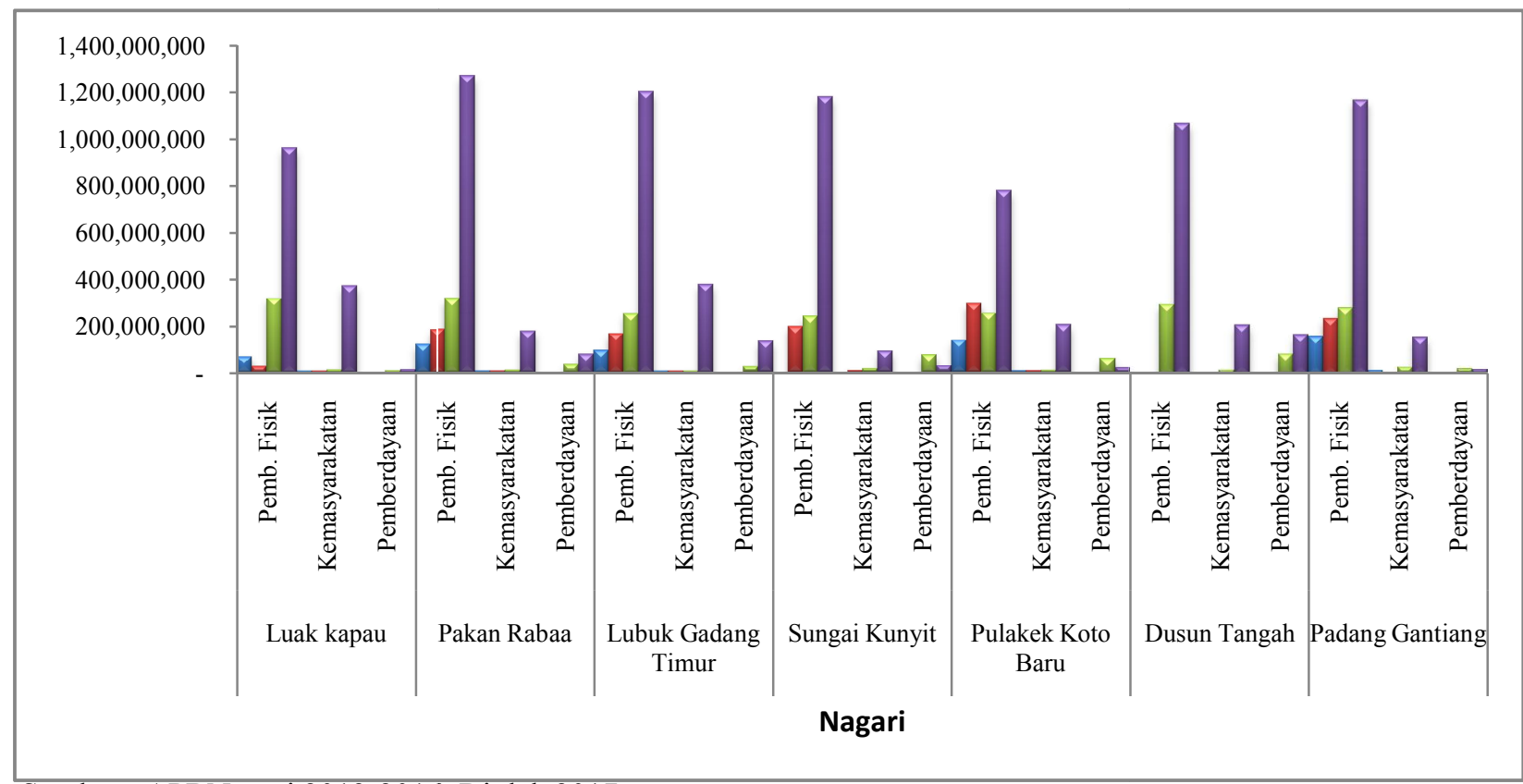

Sumber : APBNagari 2013-2016, Diolah 2017

Grafik.2 Perkembangan Pembangunan Nagari di Kabupaten Solok Selatan

Dari Grafik 2;terlihat bahwa sejak tahun 2013, pembangunan didominasi pada pembangunan Fisik, bahkan peningkatan pembangunan fisik dari tahun 2015 ke tahun 2016 lebih dari 100\%. Sedangkan pemberdayaan masyarakat yang baru dilakukan mulai tahun 2015 dengan porsi sangat kecil dibandingkan dengan pembangunan fisik. Perbandingan pembangunan fisik dengan pemberdayaan di Nagari Luak Kapau
Alam Pauh Duo tahun 2016 adalah 3 berbanding 0,4. Sedangkan Nagari Pakan Rabaa 2 berbanding1, Nagari Lubuk Gadang Timur dan Nagari Sungai Kunyit 3 berbanding 1, Nagari Pulakek Koto Baru 2 berbanding 02, dan Nagari Dusun Tangah 2 berbanding 1,6. Data tersebut memberikan gambaran kepada kitakurangnya inovasi untuk kegiatan pemberdayaan masyarakat. Pembangunan masih difokuskan pada pembangunan 
fisik seperti pembangunan jalan, irigasi, pembangunan balai-balai, namun minimnya dilaksanakan kegiatan pemberdayaan masyarakat.Kegiatan pemberdayaan masyarakat desa terkait dengan kegiatan ekonomi, sosial budaya dan lainnya yang juga terkait dengan otonomi asli nagari. Pemberdayaan masyarakat diarahakan untuk memperkuat sendi-senidi kehidupan ekonomi pedesaan yang selama ini menjadi tumpuan kehidupan masyarakat, dan juga penguatan kepasitas dan tata nilai kehidupan masyarakat nagari dari sisi sosial dan budaya yang hidup dan berkembangan pada masyaraiat nagari,

Diberlakukannya UU Nomor 6 tahun 2014 tentang Desa idealnya memberikan kesempatan kepada Nagari untuk mengembangkan potensi daerah dan kewenangan asli desa, melalui pemberdayaan masyarakat. Namun setelah dua tahun berlakunya UU Nomor
6 tahun 2014, yang terlihat menonjol adalah pembangunan fisik dan kurang menonjol program pemberdayaan masyarakat nagari di Kabupaten Solok Selatan. Nagari masih memfokuskan pada pembangunan fisik, dan kurang memprioritaskan pemberdayaan.

\section{Inovasi Penyusunan Program dan}

\section{Kegiatan Pembangunan Nagari di}

\section{Kabupaten Solok Selatan}

Dalam melakukan inovasi, ada syarat pra kondisi yang harus dimiliki oleh daerah ataupun desa/nagari dalam melakukan layanan di sektor publik tersebut. Pra syarat tersebut terdiri dari:

a. Kepemimpinan dan Pengetahuan terhadap kondisi

Kepemimpinan berpengaruh pada penyusunan inovasi pembangunan nagari. Mulai dari sejauh mana Wali Nagari mengetahui kondisi di Nagari tersebut, maupun latar belakang Wali Nagari.

Tabel 2.1 Profil Wali Nagari di Kabupaten Solok Selatan

\begin{tabular}{llllc}
\hline No & \multicolumn{1}{c}{ Nagari } & \multicolumn{1}{c}{ Wali Nagari } & $\begin{array}{c}\text { Tingkat } \\
\text { Pendidikan }\end{array}$ & $\begin{array}{c}\text { Tahun } \\
\text { dilantik }\end{array}$ \\
\hline 1 & Pakan Rabaa Utara & Novera Wandra, S.E.,M.M & S2 & 2013 \\
\hline 2 & Luak Kapau APD & Syahibul Izar, S.Sos & S1 & 2014 \\
\hline 3 & Pulakek & Marzinatal & SMA & 2014 \\
\hline 4 & Lubuk Gadang Timur & Kasri & SMA & 2014 \\
\hline 5 & Sungai Kunyit Barat & Yanuari & SMA & 2013 \\
\hline 6 & Dusun Tangah & Radiman Sigintir & SMA & 2013 \\
\hline Sumber:
\end{tabular}

Sumber: Wawancara, Diolah (2017)

Pemberdayaan masyarakat yang paling terlihat peningkatannya dari tahun
2015-2016 yaitu di Nagari Dusun Tangah.

Hal ini dikarenakan Wali Nagari Dusun 
Tangah merupakan sosok yang inovatif.

Radiman Sigintir, merupakan Wali Nagari

Dusun Tangah yang telah memimpin selama dua periode. Oleh karena itu, Wali Nagari Dusun Tangah sudah mengetahui bagaimana kondisi Nagari dan mampu merumuskan program dan kegiatan pembangunan dengan melibatkan pemberdayaan masyarakat. Selain itu, Ketua LPMN Nagari Dusun Tangah dijabat oleh Dr.Ir.Kardiman,MM, seorang yang berpendidikan doktor. Secara pengetahuan akademik, Ketua LPMN Dusun Tangah sangat mengerti bagaimana merumuskan program dan kegiatan pembangunan nagari yang inovatif sesuai dengan kebutuhan masyarakat nagari.

\section{Berbeda dengan Nagari Pakan}

Rabaa Utara, pembangunan di Nagari ini lebih berfokus pada pembangunan fisik. hal ini dikarenakan nagari ini sangat luas dan memiliki permukiman masyarakat yang terpencar. Hal ini dijelaskan oleh Wali Nagari Pakan Rabaa Utara, Novera Wandra, SE,MM. :

"Nagari Pakan Rabaa Utara memiliki geografis yang luas, jarak antar jorong jauh dan pemukiman berserakan. Sehingga pembangunan disini lebih dipusatkan untuk membangun akses penghubung antar jorong. Hal ini untuk memudahkan akses antar jorong”.
Wali Nagari Pakan Rabaa Utara merupakan lulusan S2. Secara akademik, Wali Nagari Pakan Rabaa memiliki pendidikan tinggi. Namun inovasi pembangunan belum banyak dilakukan karena kondisi georgrafis Nagari Pakan Rabaa Utara yang saat ini lebih membutuhkan pembangunan fisik.

Berbeda dengan Nagari Pakan Rabaa Utara dan Nagari Dusun Tangah, pemberdayaan masyarakat di Nagari Pulakek Koto Baru justru menurun dari tahun 2015 sampai tahun 2016. Dari hasil wawancara dengan Kaur Perencanaan Nagari Pulakek Koto Baru, Yovi Indria S.Pd, dinyatakannya bahwa :

"Apa yang harus diberdayakan di Nagari Pulakek Koto Baru tidak terlihat. Masyarakat kurang berpartisipasi dalam mengajukan program-program kepada Nagari. Hal ini karena untuk membuat suatu program, masyarakat harus mengajukan proposal kepada nagari, dan ditindaklanjuti oleh pemerintah. Tapi kenyatannya gerakan masyarakat untuk melaksanakannya sangat rendah"

Selain itu masyarakat kurang berpartisipasi, di Nagari ini LPMN juga tidak aktif, dan program yang dicanangkan kurang menyentuh kebutuhan masyarakat. "LPMN disini tidak aktif, dan tidak menentu dalam penggunaan dana. Program-program pemberdayaan sudah direncanakan di dalam pos APBNag, tapi tidak terlaksana, salah satunya karena kurangnya motivasi 
masyararakat

untuk

melaksanakannya. Selain itu

program yang diajukan juga kurang

menyentuh masyarakat."

Fenomena yang sama juga terdapat pada Nagari Luak Kapau, dimana berdasarkan wawancara dengan Wali Nagari Luak Kapau, Sohibul Izar, S.Sos bahwa:

"Pada saat penggalian gagasan di tingkat Jorong untuk perencanaan pembangunan nagari tahun 2015 dan 2016, LPMN dan Pemerintahan Nagari hanya menampung usulan dari masyarakat dari seluruh Jorong. Karena kurangya penjelasan yang detail tentang penggunaan dana desa yang disampaikan maka masyaraiat cenderung memngusulkan hal yang mudah dilihat, yaitu pembangunan fisik seperti jalan, irigasi, bangunan sekolah dan lain sebagainya. Sehingga kegiatan pemberdayaan ekonomi dan sosial budaya sangat kurang terperhatikan. LPM Nagari cukup aktif sebagai fasilitator perencanaan pembangunan nagari, meskipun pengurus bekerja sukarela dengan dana operasional yang sangat minim sekali”.

Nagari Sungai Kunyit Barat juga mengalami penurunan program pemberdayaan masyarakat. Hal ini dikarenakan wali nagari baru dilantik pada akhir 2014, sehingga belum terlalu mengetahui arahan pemberdayaan yang dibutuhkan, dan masih menyusun program untuk pemberdayaan tersebut.

\section{b. Fokus Pada hal yang penting}

Untuk poin ini, Nagari Pakan Rabaa Utara merupakan Nagari yang luas, dan akses antar jorong jauh. Sehingga untuk saat ini pembangunan lebih difokuskan untuk pembangunan fisik. contohnya pembangunan Polindes di Jorong Ulu Suliti, pembangunan jalan di depan Kantor Wali Nagari,perbaikan jalan dan jembatan, dan pembangunan pos pemuda di tiap jorong.Berbeda dengan Nagari Dusun Tangah, yang melakukan pembangunan fisik seperti rehab jalan dan jembatan,pembangunan TK/PAUD, namun disamping itu juga melakukan program pemberdayaan masyarakat seperti peningkatan kapasitas masyarakat melalui kelompok BKMT, pembinaan ninik mamak,peningkatan kapasitas pengrajin batu bata,pelatihan menjahit dan membordir, dan peningkatan kapasitas kelompok seni.

c. Kemampuan Organisasi, Insentif dan Reward

Dalam hal ini, berbicara persoalan kemampuan organisasi, tidak bisa dilepaskan dari latar belakang pendidikan dan pengalaman perangkat nagari. Di Nagari Pulakek Koto baru, staff nagari yang lulusan sarjana berjumlah tiga orang, hal yang sama juga terdapat di Nagari Pulakek Koto Baru. Sedangkan di Nagari Pakan Rabaa Utara terdapat enam staf, dua diantaranya $\mathrm{S} 1$, dua $\mathrm{D} 3$, dan lima orang lulusan SMA. Sedangkan nagari Lubuk 
Gadang Timur, dari delapan orang staf, hanya satu yang sarjana. Tingkat pendidikan mempengaruhi program, dimana, semakin tinggi pendidikan perangkat nagari, terutama di bidangnya, akan semakin besar pengetahuan akademik yang dimiliki, dan hanya perlu di praktekkan di nagari. Tapi, dilihat dari tingkat pendidikan, lebih dari 50\% lulusan SMA. Hal ini menjadi salah satu faktor inovasi program tidak berkembang, karena perangkat nagari tidak terlalu paham dengan permasalahan dan cara menganalisisnya.
Untuk persoalan insentif, Nagari Pakan Rabaa Utara paling banyak mengalokasikan dana untuk gaji karyawan. Disusul oleh Nagari Lubuk Gadang Timur, Pulakek Koto Baru, Dusun Tangah, Luak Kapau, dan Nagari Sungai Kunyit Barat. Jumlah alokasi untuk insentif perangkat nagari ini juga dipengaruhi oleh banyak wilayah bawahan yaitu Jotp zi zi rong. Nagari yang memiliki wilayah yang luas dan jorong yang banyak yaitu Lubuk Gadang Timur dan Pakan Rabaa

Utara

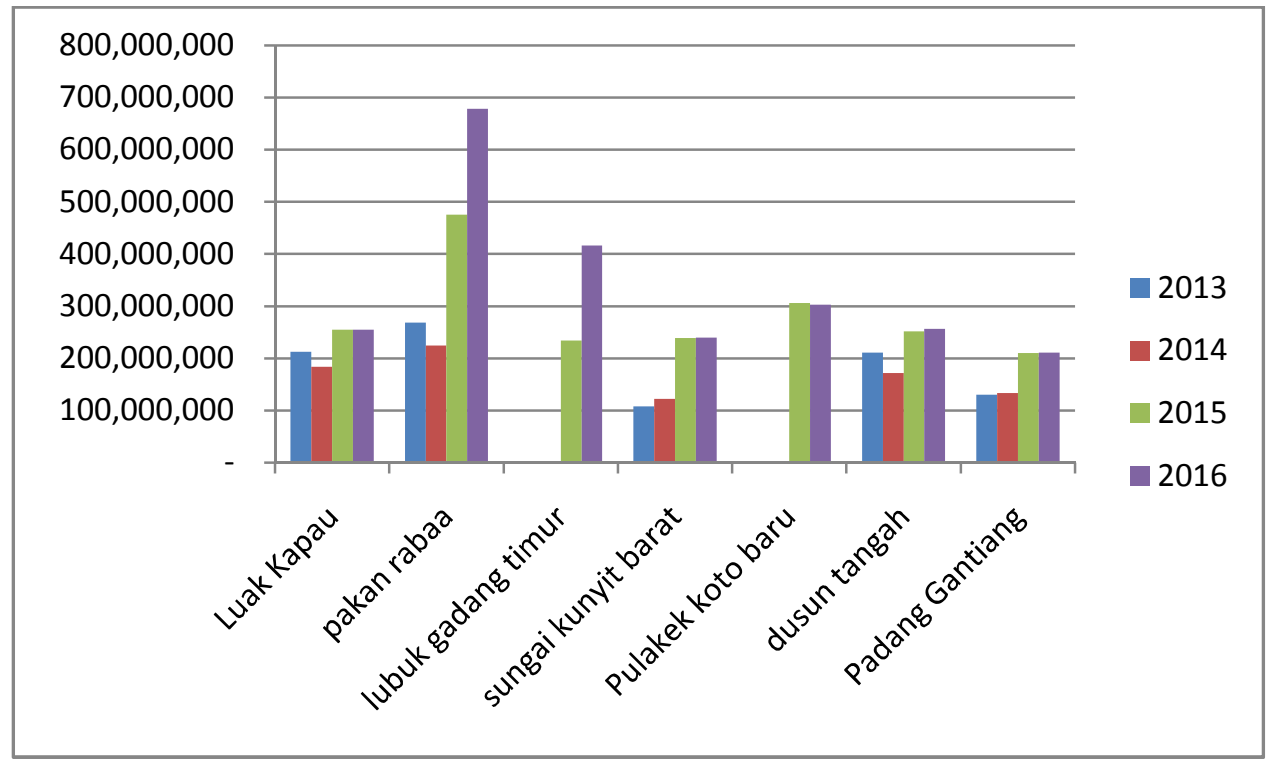

Gambar 2.3 Perkembangan Penghasilan Perangkat Nagari

Dari Gambar 2.3, dapat dilihat penghasilan perangkat nagari rata-rata sama dan cenderung meningkat dari tahun ke tahun. Tapi hal tersebut ternyata tidak berpengaruh kepada inovasi program yang dibuat oleh pemerintah nagari. Untuk dapat berinovasi, diperlukan motivasi atau daya perangsang bagi perangkat nagari. George R. dan Leslie W. (1993) mengatakan bahwa motivasi adalah 
“......getting a person to exert a high degree of effort ...." yang artinya motivasi membuat seseorang bekerja lebih berprestasi. Prestasi yang ditunjukkan oleh perangkat Nagari adalah dengan membuat inovasi program pemberdayaan masyarakat. Ravianto (1986) mengatakan bahwa salah satu faktor yang mempengaruhi motivasi adalah imbalan jasa uang. Seseorang akan bertambah motivasinya apabila mendapatkan imbalan yang sesuai bahkan lebih dari apa yang dikerjakan. Namun hal ini ternyata tidak memberikan pengaruh pada peningkatan inovasi di tujuh nagari di Kabupaten Solok Selatan. Pada umumnya, semua nagari mengalami peningkatan gaji dari tahun 2013-2016. Peningkatan tersebut tidak berbanding lurus dengan program inovasi yang dibuat. Hal ini menandakan bahwa peningkata insentif ternyata tidak membuat program inovasi bertambah.

\section{PENUTUP}

\section{Kesimpulan dan Saran}

Ditetapkannnya UU Nomor 6 tahun 2014 tentang Desa memberikan implikasi secara signifikan terhadap perubahan kebijakan dalam penyelenggaraan pemerintahan desa. Salah satu implikasinya adalah meningkatnya sumber keuangan desa terutama yang berasal dari pemerintah pusat dan pemerintah daerah dalam bentuk alokasi dana desa. Peningkatan sumber keuangan nagari tersebut ditujukan untuk meningkatkan partisipasi masyarakat dalam pembangunan nagari, terutama dalam hal pemberdayaan masyarakat, untuk menciptakan kemandirian nagari. Nagari di Kabupaten Solok Selatan masih memfokuskan pada pembangunan fisik daripada pemberdayaan masyarakat, sehingga program yang dibuat kurang inovatif. Kurangnya inovasi program dan kegiatan pembangunan nagari dipengaruhi oleh banyak hal, diantaranya kapasitas dan pengalaman wali nagari, dukungan dari lembaga-lembaga ditingkat nagari. Kemudian pemahaman masyarakat yang masih terbatas tentang pembangunan, yang lebih berorinetasikepada kegiatan pembangunan fisik dari pada kegiatan pemberdayaan. Belum tersosialisasikannya kepada masyaraiat pedoman penggunaan dana desa secara masif juga menjadi penyebab muncul usulan pembangunan fisik sejak dari penggalian gagasan dan aspirasi di tingkat jorong. Temuan penelitian ini, sebagian mendukung temuan penelitian terdahulu yaitu bahwa pengelolaan ADD untuk pembangunan fisik belum tepat sasaran (Nurliana, 2013), pengelolaan ADD belum efektif karena pos-pos anggarandalam pemanfaatan ADD tidak sesuai dengan 
kebutuhan desa, dan beberapa faktor penghambat pengelolaan ADD sehingga belum efektif menurut Okta (2004) yaitu: a) manajemen organisasi pemerintahah desa yang kurang baik; b) sumber daya manusia yang kurang; c) kurangnya sarana dan prasarana; dan d) kurangnya partisipasi masyarakat.

\section{DAFTAR PUSTAKA}

Azwardi dan Sukanto (2014), Efektifitas Alokasi Dana Nagari dan Kemiskinan di Provinsi Sumatera Selatan, Jurnal Ekonomi Pembangunan Volume 12, No.1, Juni 2014, Hal 29-41;

Bungin, Burhan (2007), Penelitian Kualitatif: Komunikasi, Ekonomi, Kebijakan Publik dan Ilmu Sosial lainnya. Kencana Pranada Media Group, Jakarta;

Drucker, Peter., (1986). Innovation and Entrepreneurship. Gramedia Pustaka Utama, Jakarta;

Hendry Maddick dan Hanif Nurcholis.

2007.Teori dan Praktik

Pemerintahan dan Otonomi

Daerah. Jakarta: Grasindo;

Ian McPhee, 2009, Innovation in the Public Sector: Enabling Better Performance, Driving New Directions, Commonwealth of Australia;

Komisi Pemberantasan Korupsi (2015), Laporan Hasil Kajian Pengelolaan Keuangan Nagari: Alokasi Dana Nagari dan Dana Nagari. (Direktorat Penelitian dan Pengembangan);
Lexy Moleong. 1998. Metode Penelitian Kualitatif. Bandung: Remaja Rosda Karya;

PP Nomor 43 tahun 2014 tentang Peraturan Pelaksanaan UU Nomor 6 tahun 2014;

PP Nomor 60 tahun 2014 tentang Dana Nagari yang bersumber dari APBN;

PP Nomor 22 tahun 2015 tentang Perubahan PP Nomor 60 tahun 2014;

Permendagri Nomor: 111-114/2014 tentang Pedoman Teknis Peraturan Desa;

Permenkeu Nomor: 250/PMK.07/2014 tentang Pengalokasian Transfer ke Daerah dan Dana Nagari;

Permenkeu Nomor: 241/PMK.072014 tentang Pelaksanaan dan Pertanggunjawaban Transfer ke Daerah dan Dana Nagari;

Rosalinda LPD, Okta (2014), Pengelolaan Alokasi Dana Nagari (ADD) Dalam Menunjang Pembangunan Pengarian (Studi Kasus: Desa Segodorejo dan Desa Ploso Kerep Kecamatan Sumobito Kabupaten Jombang, Jurusan Ilmu Ekonomi Fakultas Ekonomi dan Bisnis Universitas Brawijaya, Malang;

Hanida. Rozidateno P, Bimbi Irawan dan Syamsurizaldi (2015), Analysis of Policy of Planning and Budgeting Making Local Government Planning Policy More Significant in Indonesia, IJASOS International e-Journal Advances in Social Sciences, Vol.1 No.2, 2015;

Wirhatnolo, Randy R, dan Riant Nugroho D (2006), Manajemen Pembangunan Indonesia, Elex Media Komputindo;

UU Nomor 6 tahun 2014 tentang Desa 
96 | Jurnal Pembangunan Nagari | Volume 3 Nomor 1 Edisi Juni 2018 : 75 - 96 